\title{
THROUGH THE LOOKING GLASS, DARKLY: RESURFICE CORP. V. HANKE
}

\section{Vaughan Black’ and DaVid Cheifetz ${ }^{*}$}

The Supreme Court of Canada's brief reasons in Resurfice Corp. v. Hanke' will likely have effects disproportionate to their length. Hanke purports to mark a defendant-favouring turn in civil liability. Hanke asserts that the but-for test is the test for factual causation in almost all accidentally-caused injuries. This aids defendants because it eliminates from ordinary use what some lawyers and judges have asserted is a more easily satisfied alternative to the but-for test, the material-contribution test. If judges pay attention to the advertised goal of Hanke, there will be cases where factual causation is not established under the but-for test, where it likely would have been under material contribution.

Causation is an area that has been characterized by uncertainty for at least five decades. ${ }^{2}$ Hanke attempts to reduce that. However, given Hanke's content, we believe that this attempt has mostly failed. The clarity or certainty it adds to the murky case law is minimal. It is doubtful that Hanke's laudable objective of rendering use of the material-contribution test an exceptional event will come to pass. In both respects, Hanke is a missed opportunity.

\section{The Facts AND Holdings}

Mr. Hanke mistook the gasoline tank for the water tank on a machine he was preparing to use. He put water into the fucl tank, creating vapourized gasoline which escaped and was ignited. He was badly burned. He sued both the machine's designer and distributor, alleging that the accident was due to faulty design. The trial judge dismissed the action, holding that Hanke had not established that his injuries were caused by negligent design. ${ }^{3}$

The Alberta Court of Appeal unanimously allowed Hanke's appeal and ordered a new trial. It held that the trial judge erred in applying the but-for test for factual causation because that test was unworkable on the facts as there was more than one potential cause for Hanke's injuries. ${ }^{4}$ It relied on and quoted the Supreme Court of Canada's 2001 decision in Walker Estate v. York Finch General Hospital:

- Professor, Dalhousie Law School, Halifax.

- Partner, Bennett Best Bum l.L.P, Toronlo. We thank Lewis Klar and Russell Brown. We have benefited from our discussions with them.

2007 SCC 7, 278 D.L.R. (41h) 643 [Hankc].

Snell v. Farrell, [1990] 2 S.C.R. 31 I [Snell]: Warch v: Stramarc Lid. [1991] 171 C.L.R. 506 (H.C.A.); Bonnington Castings lid. $\because$ Wardlaw, [1956] A.C. 613 [Bonnington Castings]; McGhee v. National Coal Bourd, [1973] I W.L.R. I (H.L.) [McGhee].

Hanke v. Resurfice Corp., 2003 ABQB 616, 333 A.R. 371 [Hanke (Q.B.)].

Hanke v. Resurfice Corp., 2005 ABCA 383. 380 A.R. 216 [Hanke (C.A.)].

Walker Estate v. York Finch General Hospilal, 2001 SCC 23, [2001] I S.C.R. 647 al paras. 87-88 [Walker]. 
Where there is more than one potential cause, the "material contribution" test should be used.... As the Appellant's act of inserting or leaving the hose in the gasoline tank may have contributed, the "material contribution" test should have been used. The "but for" test was unworkable in these circumstances.

Applying Walker and Athey v. Leonati, ${ }^{7}$ the Alberta Court of Appeal held that causation should have been determined on the material-contribution standard. ${ }^{8} \mathrm{~A}$ new trial was required since Hanke might have been able to establish causation on that test.

A nine-judge panel of the Supreme Court of Canada unanimously allowed the defendants' appeal. In succinct reasons written by McLachlin C.J.C., the Court held that the trial judge got both law and fact right."

In recent years, especially in the United Kingdom, judges have expended much effort wrestling with the question of when, in the interests of justice, courts may depart from the traditional but-for test for causation and employ a more easily satisfied test. The House of Lords has issued four long, complex judgments on the matter since 2003, each with considered references to both United Kingdom and other Commonwealth case law. ${ }^{10}$ Hanke grapples with the same difficult issues as did the House of Lords. Unlike the House of Lords decisions, Hanke does so in bare-bones fashion. The Supreme Court's curt reasons mention no cases other than its own" and no scholarly writing on the causation issues beyond an acknowledgment that some exists. ${ }^{12}$ That, on its own, is not necessarily cause for concern. Many will prefer the brevity of the Supreme Court's approach in Hanke to the alternative of wading through lengthy judicial dilations. But, even if the pithy, headnote-like nature of the Hanke judgment is not reason for concern, its content is.

\section{The SUPREME COURT'S ReASONING in HANKE}

\section{A. FORESEEABILITY}

The first part of the Supreme Court's analysis is headed "Foreseeability." The gist of this brief six-paragraph section is that the Alberta Court of Appeal erred in intervening because

- Hanke (C.A.), supra note 4 at para. 14.

[1996] 3 S.C.R. 458 [Athey].

Hanke (C.A.), supra nole 4 at paras. 12-14, 22.

Hanke, supra note 1.

Fairchildv. Glenhaven Funeral Senvices Lidd, [2002] UKHL 22, [2003] I A.C. 32 [Fairchild]; Chester v. Afshar, [2004] UKHL 41, [2005] I A.C. 134; Gregg v. Scott, [2005] UKHL 2, [2005] 2 A.C. 176

[Gregg]; Barker v. Corws (UK Lid.), [2006] UKHL 20, [2006] 2 A.C. 572 [Barker]. Together the specches in these four cases total over 200 pages. The leading decisions ofCanadian provincial appellate courts are: Wiebe v. Canada (Attorney General), $2006 \mathrm{MBCA} 159,212 \mathrm{Man}$. R. (2d) 99, leave to appeal to S.C.C. refused, 31860 (10 May 2007); Mooney v. British Columbia (Auorney General), 2004 BCCA 402. 31 B.C.L.R. (4th) 61, leave to appeal to S.C.C. refused, 30546 (3 Manch 2005) [Mooney]; Cottrelle v. Gerrard (2003), 67 O.R. (3d) 737, leave to appeal to S.C.C. refused. 30109 (22 April 2004) [Cotrelle].

"Mainly, it seems, to give the impression that its own decisions in the area were clear and consistent.

12 The one article cited is for a point of tort principle, but not causation: Hanke, supra note I at para. 6 , citing Lewis Klar, "Downsizing Torts" in Nicholas J. Mullany \& Allen M. Linden, eds., Torts Tomorrow: A Tribute to John Fleming (Sydney, Austl.: LBC Information Services, 1998) 305. 
the trial judge did not make any errors. ${ }^{13}$ section is mainly a reminder that appeal courts must not intervene simply because they have different views of the facts. The trial judge found there was no factual basis for the allegations of negligent design. ${ }^{14}$ The Court of Appeal had held that the trial judge did not adequately consider the evidence on the design issue as it related to the foreseeability of an experienced user confusing the tanks. ${ }^{15}$ The Supreme Court held that there was evidence to support all the trial court's findings and that the trial judge got the law right. ${ }^{16}$ The Court emphasized than an appeal court can interfere with a trial judge's finding of fact, or mixed fact and law, only where the trial judge made some palpable and overriding error. No such error was present.

There is nothing in this section of the Supreme Court's analysis that attempts to clarify tort doctrine, apart from a statement that the Alberta Court of Appeal erred in stating that the trial judge should have taken account of the seriousness of the injury or the relative financial situations of the plaintiff and defendants when assessing foreseeability. ${ }^{17}$ This seems axiomatic. In saying that, we do not mean to suggest that these factors are never pertinent in negligence, but simply that the Court is right in saying that they are not pertinent to an assessment of foreseeability.

One aspect of this section of Hanke merits brief comment. It arises from the Supreme Court's use of the heading "Foreseeability." Foresceability is a concept that plays a role in several aspects of negligence doctrine. It is relevant to determining whether a duty of care exists. ${ }^{18}$ It also plays a role in assessing whether a standard of care has been breached. ${ }^{19}$ However, when deployed as a stand-alone term, foreseeability usually refers to an issue that also goes under the rubrics "remoteness" and "proximate cause." It denotes the situation where a defendant has been found to have breached an applicable standard of care and has been found to have factually caused the plaintiff's injury, but where that injury (or perhaps just certain elements of it) might for some reason be ineligible for legal protection on the facts of the case. These reasons might include factors such as the number of steps in the causal chain between the initial negligence and the resulting injury, or the freakish nature of that causal chain. ${ }^{20}$

In Hanke, it is not clear which meaning the Supreme Court meant to invoke in its use of the term foreseeability. In our reading, the best interpretation is that the Court was talking about the standard of care, or at least about the stage of assessing the standard of care which

Hanke, supru note 1 at paras. 6-12.

Hanke (Q.B.), supra note 3.

Hanke (C.A.), supra note 4.

Hanke, supra note 1 at para 10, referring to Housen v. Nikolaisen. 2002 SCC 33, [2002] 2 S.C.R. 235.

llanke, ibid. at para 11. See also Dobson (Lirigation Guardian of) v. Dobson, [1999] 2 S.C.R. 753 at paras. 71-75 (deep pockets); Missiapha v. Culligan of Canada Lid. (2006), 84 O.R. (3d) 457 (C.A.), leave to appeal granted, 31902 (2I June 2007) (foresecability; significance of nature and seriousness of consequences).

Donoghue v. Stevenson, [1932] A.C. 562 (H.L.); Cooper v. Hobart, 2001 SCC 79, [2001] 3 S.C.R. 537. Bolton V. Stone, [1951] A.C. 850 (H.L.); Overseas Tankship (U.K.) Lul. v. The Miller Steamship Co. Lud. (Wagon Mound No. 2), [1967] I A.C. 617 (P.C.).

See Lewis Klar, Tort Law, 3d ed. (Toronto: Carswell, 2003) at 163-71. 
necessitates an assessment of foreseeability." It would have been better if the Court had remembered to acknowledge that "foreseeability" is used in different ways in negligence claims, and had been a little clearer about the usage. That, however, is a peripheral matter. The greater portion of the Hanke judgment deals with factual causation and is the focus of the remainder of this comment.

\section{B. Causation}

It was not necessary that the Supreme Court deal with factual causation, once it decided the standard of care issue in the defendants' favour. The finding that the standard of care had been met - that the defendants had not been negligent - was sufficient to defeat Hanke's claim. However, causation was a separate ground of appeal for which leave was given. Moreover it is an area of the law in need of clarification. As we, independently ${ }^{22}$ and jointly, ${ }^{23}$ and others ${ }^{24}$ have pointed out, Canadian law on causation has been sorely confused since the Supreme Court's 1996 judgment in Alhey. ${ }^{25}$ So, it is neither surprising nor troubling that the Supreme Court in Hanke chose to address causation, even though it was unnecessary. Indeed, it was potentially helpful that the Court chose to address this, given what the Alberta Court of Appeal had said. Recall that it held that the material-contribution test must be used whenever there is more than one potential cause for the injury. ${ }^{26}$ The Supreme Court disagreed. It recognized that accepting the Alberta Court of Appeal's analysis effectively eliminated the but-for test, making material contribution "the default test."27

Unfortunately, the manner in which the causation issue was framed at trial and appeal produces problems of clarity. It makes the entire discussion of causation abstract. The discussion in Hanke takes place without a factual underpinning to help establish context and clarify general propositions. This occurs because an assessment of causation normally involves a comparison of $(1)$ the way things turned out in the real world after the defendant's breach (including, if necessary, conclusions as to how things will probably unfold in the future), and (2) the way things would probably have occurred had the defendant met the applicable standard of care. However, the trial judge had simply found only that the

The Alberla Court of Appeal, however, appears to have meant foreseeability relating to the standard of care and adequacy of the design, notwithstanding that it mentioned lactors relating to foreseeabilty as proximate cause and remoleness issues: /lanke (C.A.), supru note 4 at paras. 19-21.

:2 Vaughan Black, "The Transiormation of Causation in the Supreme Coun: Dilution and 'Policyization," in Todd Archibald \& Michacl Cochranc, eds., Ammual Review of Civil Litigation 2002 (Toronto: Carswell, 2003) 187 [Black, "Dilution and 'Policyization'"]; Dennis Klimehuk \& Vaughan Black "A Comment on Athey v. Leonati: Causation, Damages and Thin Skulls" (1997) 3I U.B.C. L. Rev. 163; Vaughan Black, "A Farewell to Cause: Canadian Red Cross Society v. Walker Estate” (2001) 24 Advocates' Q. 478; David Cheifetr., "The Snell Inference and Material Contribution: Defining the Indefinable and Hunting the Causative Snark" (2005) 30 Advocates' Q. I [Cheifetz, "The Snell Inference"].

2) David Cheifetz\& Vaughan Black, "Malterial Contribution and Quantum Uncertainty: Hanke v. Resurfice Corp." (2006) 43 Can. Bus. L.J. 155 [Cheiftetz \& Black, "Material Contribution"]. Comment on Briglio v. Fantkner" (2000) 34 U.B.C. L. Rev. 317; Lara Khoury. Uncersain Causation in Medical Liability (Oxford: Ilart Publishing, 2006).

:3 Supra note 7.

io Hanke (C.A.), supra note 4 at para. 14.

"I Itanke, supra note I at paras. 19, 29. We have made this point before, see Cheifetz \& Black, "Malerial Contribution," supra note 23. 
defendants had not breached their standard of care and that they had not caused Hanke's injuries. He did not make the counterfactual findings because he did not have to. As the Supreme Court simply affirmed the trial judge's conclusions, it did not have the opportunity to perform the real and counterfactual comparison that constitutes the causal inquiry.

That comparison could only have taken place if the trial judge had said something like this: "Perhaps I am wrong in concluding that the defendants' actions in designing and distributing this machine met their standard of care. Perhaps satisfying the standard of care would have resulted in the manufacture and sale of a machine in which it was more difficult to confuse the fuel and water tanks." There could then have been a linding as to how the machine would have looked had this higher standard of care been met. That would have set the scene for the causal inquiry - an inquiry into whether the plaintiff would have confused the two tanks even on a machine designed to make such confusion less likely. However, no such finding was ever made. That does not mean that the Supreme Court should not have taken the opportunity to say something helpful about the law of causation. It does mean that readers of Hanke cannot usefully turn to findings of fact for help in understanding the Supreme Court's pronouncements.

The Court's statements about factual causation are brief. They set out the rules by which Canadian judges will determine whether they are to apply the but-for test or are to resort to a more easily satisfied standard, currently known as the material-contribution test. ${ }^{28}$ The Supreme Court had approved the material-contribution test in 1996 in Athey, in which it described the test as follows: in circumstances where the but-for test is unworkable, causation is established if the defendant's negligence materially contributed to the occurrence of the injury; and the negligence materially contributed if its involvement in the causation process is more than minimal. ${ }^{24}$ Two important questions have reigned since the approval of the material-contribution test: when is that test available and what is its content? Neither Athey nor subsequent decisions adequately answer these two questions. Part of the reason for this failure is that the parameters of the material-contribution test as set out in Athey are so uncertain that they are open to a myriad of different meanings. ${ }^{30}$

Hanke provides some answers to the first of those questions and. inferentially, it tells us something about the second. In general terms, its answers can be summarized: (1) the but-for test is the ordinarily applicable test and the material-contribution test is available only in exceptional instances; and (2) the material-contribution test is distinct from the but-for test and represents a more easily fulfilled causal standard, probably amounting to no more than

2x The discussion of causation in Monke, ibid., starts at para. 16. Paragraphs 16-17 appear under the subheading "Comparative Blameworthiness." The Alberta Court of Appeal had held that the trial judge also erred by failing to consider whether the incident could have been the fault of both Hanke and the defendants. The Supreme Court held that he did not. The causation discussion is introduced under the sub-heading "Tust For Causation," commencing at para. 18. Paragraphs 18-23 deal with but-for; paras. 24-28 with material contribution. Paragraph 29 is the summary.

2* Athey, supra nole 7 at para. 15; Homington Castings, supra note 2; Me Cihee, supra note 2.

3o The cases show at least 15 diflenent, mostly inconsistent, answers to when material contribution was applicable (see Cheifetz, "The Sinell Inference," supra nole 22 at 71-73) and 11 different, mostly inconsistent, meanings for unworkable (see Cheifety, ihid., at 83-85). 
an inquiry into whether the defendant has increased the risk of the plaintiff suffering the type of injury the plaintiff did in fact suffer.

Athey had held that resort to the material-contribution test was available whenever the butfor test is unworkable. ${ }^{31}$ However, Athey did not define "unworkable"; it offered no explanation of what unworkable might mean. The cases cited for the material-contribution tes $^{32}$ do not provide an explanation. In subsequent cases, unworkability turned out to be neither a certain nor even a coherent standard. ${ }^{33}$ In Hanke, it was the Alberta Court of Appeal's holding that the unworkability test in Athey had been satisfied that prompted it to order a new trial where Hanke would have the chance to prove causation on the materialcontribution test. That decision was typical of post-Athey applications of the unworkability test. The Court of Appeal simply declared the but-for test to be unworkable, without explaining why that was so. ${ }^{34}$ The assertion that but-for was unworkable, because there was more than one potential cause of the incident, was a conclusion (and not a valid one), not an explanation.

\section{WHEN DOES MATERIAL CONTRIBUTION APPLY?}

In Hanke the Supreme Court reaffirmed the use of an unworkability criterion, held that unworkability did not exist on the facts, then attempted to give unworkability useful content, having declared that the mere fact that the harm could have more than one potential cause was not content. The Court laid down a two-part test for when judges are to apply the material-contribution test. It is Hanke's two-part test, rather than Athey's test of unworkability, that will become part of the new framework controlling use of the materialcontribution test, ultimately defining the meaning of "unworkable."

One of Hanke's two new triggering factors is that

it must be clear that the defendant breached a duty of care owed to the plaintiff, thereby exposing the plaintiff to an unreasonable risk of injury, and the plaintiff must have suffered that form of injury. In other words, the plaintiff's injury must fall within the ambit of the risk created by the defendant's breach. ${ }^{35}$

The other limb of the new test is impossibility:

it must be impossible for the plaintiff to prove that the defendant's negligence caused the plaintiff's injury using the 'but for' test. The impossibility must be due to factors that are outside of the plaintif's control; for example, current limits of scientific knowledge. ${ }^{36}$

See the articles and texts referred to in supra notes 22-24.

Hanke (C.A.), supra note 4 at para. 14.

Hanke, supra note 1 at para. 25 [emphasis added].

Ibid. at para. 25. As mentioned, the Supreme Court cited only its own cases, mentioning only Cook and Walker (but not Athey) in its discussion of material contribution. Readers interested in a possible source for the text of the Hanke pronouncements should compare the text of Hanke's two general principles to Haag i: Marshall (1989), 61 D.L.R. (4th) at paras. 20-26, particularly paras. 23-24 (B.C.C.A.). 
The Court completed its sketch ${ }^{37}$ of the factors with this explanation of their consequences:

In those exceptional cases where these two requirements are satisfied, liability may be imposed, even though the 'but for' test is not satisfied, because it would offend basie notions of faimess and justice to deny liability by applying a 'but for' approach. ${ }^{38}$

The Court then gave two examples from its own previous cases which would serve as illustrations of the satisfaction of the two-part test: its 1951 decision in the careless hunter case Cook $v$. Lewis, ${ }^{39}$ and its decision half a century later in the HIV-transfusion case Walker. ${ }^{+0}$

Any clarification of Athey's unworkability criterion that Hanke's two-part test provides is minimal. There are at least two sources of problems and confusion in Hanke's test. The first is the formulation of triggering criteria themselves. The test as set out in Hanke has an initial air of plausibility and certitude, yet a moment's reflection reveals that the Court's words are fraught with imprecision and tautology. The second source of confusion arises from the examples used to illustrate the test; examples presumably chosen for their illuminating properties but which have the opposite effect.

We will first consider the criteria. The first-mentioned - injury falling within the scope of the risk - will, necessarily and by definition of what constitutes negligence, be satisfied every time the other elements of the tort of negligence ${ }^{41}$ are satisfied. All conduct creates risk. Negligence requires unreasonable increase in risk. ${ }^{42}$ A plaintiff who has demonstrated the existence of a duty of care, breach of that duty, and injury within the scope of the risk the elements of the tort of negligence other than causation - will invariably have satisfied the "injury falling within the scope of the risk" criterion. Conversely, if a plaintiff has not suffered an injury that was of the type that fell within the duty of care imposed on the defendant, that plaintiff will never get to the causation threshold. The case will have failed at an earlier stage. So, the "injury falling within the scope of the risk" criterion may seem coherent but does nothing to advance its advertised goal of making the application of the material contribution test exceptional. In fact, it does nothing.

The bare-bones manner of the Supreme Court's declaration of the "ambit of risk" requirement leaves room to wonder whether the Court appreciates the extent of the debate as to whether the phrase is capable of useful meaning. How does one establish the "ambit" of the risk? Is the ambit to be defined by normative considerations or economic considerations or other factors and in what combination? The extent of the debate will become readily apparent if a literature search is done for scholarship on risks analyses and negligence. because it may also tell us something about the content of those situations which will satisfy both branches of the test. 
Also, it is at least curious that the Supreme Court provided this criterion with no acknowledgement that it is inconsistent with its explicit statements in Snell, ${ }^{43}$ Laferrière $v$. Lawson, ${ }^{44}$ Arndt v. Smith, ${ }^{, 5}$ and St. Jean v. Mercier, ${ }^{46}$ all of which rejected the use of material contribution to the increased risk of injury as sufficient proof of factual causation. "Exposing the plaintiff to an unreasonable risk of injury" ${ }^{\prime \prime 7}$ would have to amount to at least a material contribution of some type. It could not be relevant were it something less. Gonthier J. wrote for the court in Mercier:

The [Quebec] Court of Appeal appropriately said that it is insufficient to show that the defendant created a risk of harm and that the harm subsequently occurred within the ambit of the risk created. To the extent that such a notion is a separate means of proof with a less stringent standard to satisfy, Snell ... and definitely Laferrière ... should have put an end to such attempts at circumventing the traditional nules of proof on the balance of probabilities. ${ }^{48}$

In short, the "augmented risk" meaning of material contribution should not be available until the Supreme Court formally overrules these recent decisions. ${ }^{49}$

Having said that, we agree with Lewis Klar and others that a practice exists which amounts to holding that augmented risk is sufficient proof of factual causation, even if the judiciary will not admit it or does not recognize it. Referring to the effect of Snell, Klar wrote: "Thus, even in cases where the evidence clearly does not support the factual proposition that the defendants' negligence caused the plaintiff's injuries, as a matter of probabilities, defendants have been found fully liable for a plaintiff's injuries." ${ }^{\text {"50 }}$

The other criterion in Hanke's two-part test, impossibility, is not quite so empty. However, it is vastly overbroad as formulated. The Supreme Court does not provide any explanation of the limit on the relevant reasons for why the factors are outside of the plaintiff's control. "Current limits of scientific knowledge"s1 is offered only as an example; not as an instance of a necessary limiting condition. ${ }^{32}$ There will be many cases where, for reasons outside a plaintiff's control, it is impossible for the plaintiff to demonstrate causation. For instance, it

"2 However, the "current limits of scientific knowledge" is a necessary condition in both Fairchild and

Barker, supra note 10.

Supra note 2, unless augmented risk is held to satisfy Sopinka J.' $s$ substantial connection requirement, so thut it is deemed not to amount to "compensaling plaintiffs where a substantial connection between the injury and the defendant's conduct is absent" (at para. 326-27).

[1991] I S.C.R. 541 at 609 [Lawson].

[1997] 2 S.C.R. 539 at para. 43 [Armdf].

2002 SCC IS, [2002] I S.C.R. 491 at paras. 56-57, 116 [Afercier].

llanke, stupra note I al para. 25.

Supra note 46 at para. 116 [footnotes omitted].

Here we are repeating arguments made in 2006: see Cheifetz \& Black, "Material Contribution," supra note 23 at 162-63. See also David Cheifetz, "Materially Increasing The Risk of Injury As Faclual Cause of Injury: Fairchild v. Glenhaven Fumeral Services Lid. in Canada" (2004) 29 Advocates' Q. 253 , especially at 261-67. Chicf Justice MeLachlin has participated in all of the Supreme Court's decisions in the canon establishing its factual causation jurisprudence, starting with Srell.

Klar, "Downsizing Tort," supra nole 12 at $311-12$. See also Klar, Tort Law, supra note 20 generally at 401-404 and especially at 4023-403: "To allow an inference of cause to be drawn even where there is no scientific evidence of a probable connection between negligence and injury is in effect to accept the essential principle of $M c G$ Gee." See also Khoury, supra note 24.

Hanke, supra note 1 at para. 25. 
is impossible for us to demonstrate that $\mathrm{Al}$ Gore invented the Internet. That does not mean that the but-for standard is the wrong inquiry for addressing the question of whether he (or anybody else) did, or that some other criterion should be brought to bear. The example is silly but the point is not. There are an infinite number of cases where, for reasons beyond a plaintiff's control which have nothing to do with what caused what, the plaintiff cannot demonstrate that the defendant's actions had any causal factual relationship with the plaintiff's injury. In many of those cases, that creates no dissatisfaction with the but-for test, nor should it.

The problem is Hanke's focus on the impossibility of the plaintiff proving causation. Perhaps the Supreme Court's words, "impossible for the plaintiff to prove," ${ }^{3}$ could be rendered more helpful if we understood them as something along these lines: "impossible for anyone to either prove or disprove even if every bit of evidence that could ever be available to the moment of trial were put before the court." This accords with the judgment of the House of Lords when wrestling with the same problem in Fairchild. ${ }^{\text {st }}$ In that case, Lord Nicholls suggested we might turn to the material-contribution test "when, in the present state of medical knowledge, no more exact causal connection is ever capable of being established." His focus was not on whether the plaintiff cannot prove causation, as it is in the Hanke formulation, but on whether anyone can prove (or disprove) it. ${ }^{56}$ Lord Nicholls emphasized this when he added that his suggested criterion for availability of the materialcontribution test "is emphatically not intended to lead to ... a relaxation whenever a plaintiff has difficulty, perhaps understandable difficulty, in discharging the burden of proof resting on him."s7

Lord Hoffmann made a similar point in Fairchild when he authorized resort to the material-contribution test when "medical science cannot prove" question. In a similar vein, their Lordships employed or approved the phrase "impossible to say" at several points. ${ }^{59}$ We suggest that unless the Supreme Court's words in Hanke "impossible for the plaintiff to prove" (or disprove)," Hanke will make the material-contribution test available in too many cases.

So much for analysis of the criteria. What about the two examples the Supreme Court offered? The first was Cook, ${ }^{61}$ which involved two hunters who discharged their weapons simultaneously. The choice is curious. Cook was not decided on the material-contribution standard. There the Supreme Court adhered to the but-for test but reversed the onus, imposing on the defendants the burden of disproving but-for causation. Hanke's suggestion that it was, or could have been, decided under material contribution seems bound to cause

Hanke, supra note 1 at para. 25 [emphasis added].

Supra note 10.

lbid. at para. 42.

Compare Cottrelle, supra note 10 at para. 30: "The "but for' test has been relaxed as 'unworkable" in cases where, practically speaking, it is impossible to determine the precise cause of the injury."

Fairchild, supra note 10 at para. 43.

Ibld. at para. 61; see also Cottrelle, supra nole 10 at para. 30.

The quoted words are those of Lord Hoflmann in Foirchild, supra note 10 at paras. 46, 72. The same words are quoted approvingly by Lord Hutton at para. 113, and used by Lord Rodger at para. 158.

Hanke, supra note 1 at para. 25.

Supra note 39. 
confusion in the choice of test. Also, the result of a Cook-type case seems to be different under cach test, for similar situations, depending on how the evidence is balanced as between injured person and wrongdoers, and as between the wrongdoers. Under Cook, at the end of the trial, if the evidence is not equally balanced with respect to the conduct of both defendants, the Cook doctrine no longer applies. The case must be dismissed against one of the defendants. ${ }^{62}$ The evidence shows that that defendant's conduct was not a probable cause. Under Hanke's material-contribution test (and its unreasonably-augmented risk standard), however, both defendants may still be held liable even if the evidence is not equally balanced against them. ${ }^{63}$ In describing Cook as a material-contribution case, the Supreme Court may have been advising that the material-contribution test sketched in Hanke is the only plaintifffavouring alternative to the but-for test that will now be countenanced. It would have been better if the Court had stated more clearly its purpose in referring to Cook.

The second example the Court proffered to elucidate Hanke's new test is even less helpful. Chief Justice McLachlin wrote that the new test had been satisfied in Walker as "it was impossible to prove that the donor whose tainted blood infected the plaintiff would not have given blood if the defendant had properly warned him against donating blood." ${ }^{64}$ She sought to generalize that holding: "[A]n exception to the 'but for' test may be where it is impossible to prove what a particular person in the causal chain would have done had the defendant not committed a negligent act or omission, thus breaking the "but for' for chain of causation."

There are four problems with this effort to generalize when the criteria for the Hanke test for the availability of the material-contribution test might be satisfied. First, it does not fit the Supreme Court's goal of confining the material-contribution test to special circumstances. A large number of causal chains require speculation as to some hypothetical decision of a particular person. All claims for fraud and misrepresentation do, as do all cases of failure to warn (for instance by manufacturers and doctors), failure to provide safety equipment, and many others as well. Such cases are not exceptional, or at least not rare. ${ }^{60}$

The second problem with the generalization is that it is satisfied by the facts of Hanke. Assume for the purposes of discussion that the defendants had fallen below their standard of care in making and distributing the machine in question. The but-for causal inquiry in Hanke would then require speculation as to what a particular person (the plaintiff) would have done with a properly designed machine. That means that while Hanke's facts satisfy the test the Supreme Court says we can take from Walker, the Court did not think the new material-contribution test should be applied in Hanke; therefore, the Walker example is obfuscatory.

(1)

\section{lbid. at 840-41.}

We note that under the /Hanke material-contribution test, the plaintiffs risk of non-persuasion on the factual causation inquiry has been effectively subsumed into the standard-of-care inquiry.

Hanke, supra nole 1 at para. 28, nelerring to Walker, supra note 5. It is curious that MeLachl in C.J.C. did not mention that the alternative ratio in Walker is that it was possible to establish factual causation on a but-for basis.

Janke, ibid.

See Vaughan Black, "Decision Causation: Pandora's Tool-Box" in Jason W. Neyers, Erika Chamberlain \& Stephen G.A. Pitel, eds. Emerging Issues in Tort Law (Oxford: Hart Publishing. 2007) 309. 
A third problem arising from Hanke's use of the Walker example is in trying to square Hanke's statements with the results in the leading provincial-appellate cases Mooney ${ }^{67}$ and Cottrelle. ${ }^{68}$ The Supreme Court refused leave in both these cases. Yet, both cases fit every aspect of the Court's pronouncements under both prongs of the Hanke test. We think it is worth asking what changed in Canadian law between those two cases and Hanke?

A fourth problem is that in most, if not all, cases of injury caused by negligent delay in providing or the negligent provision of medical treatment, the plaintiff is able to show that the negligence increased the possibility of the occurrence of the injury that resulted (or exacerbated the existing problem) to some extent. The problem is that in some cases the injured person cannot show the negligence probably caused the injury; the evidence goes no farther than possibility. Assume the facts fit Hanke's impossibility prong and the injury that manifested is of the type that would be reasonably expected if the physician were negligent. Current Canadian law mandates that factual causation in those cases must be proven on a balance of probability, and so these actions must fail. ${ }^{69}$ Did the Supreme Court intend to overrule that law? Or, will the Hanke material-contribution test not apply to cases involving medical malpractice, even if it applies elsewhere? ${ }^{70}$

Perhaps we are wrong in reading Hanke to mean that the "impossibility" standard is satisfied every time the causal chain requires speculation as to some counterfactual decision. Perhaps the Surpeme Court meant that resorting to the material-contribution test will be justified only in the sub-set of cases which require speculations as to hypothetical decisions and where it is impossible to establish on the balance of probability what a particular person would have done. This reading would then require judges and juries to distinguish between those cases where such speculation is possible and those where it is not. That line will not be easy to draw, though it may be plausible. In Walker, an experienced trial judge found such speculation to be entirely possible. Justice Borins applied the but-for test, which included speculation as to a hypothetical decision, and confidently concluded that the plaintiff failed to establish causation on the but-for standard. ${ }^{71}$ However, according to Hanke, Walker is to be understood as a case where proof on the but-for standard was impossible. ${ }^{72}$ Hanke does not explain why. We wonder if the basis of the distinction would ultimately be found in expediency, not principle.

Hanke's interpretation of Walker is puzzling. It ignores the alternative holding in Walker where the Supreme Court employed the but-for standard (including speculation as to a hypothetical decision) and found it was satisfied. ${ }^{73}$ Walker has alternative, inconsistent holdings of equal status: (1) the but-for standard is satisfied and (2) it is impossible to establish proof by the but-for standard so the material-contribution test may be used. In short,

Supra note 10.

thid.

Lawson, supra note 44 at 608-609; Mercier, supra note 46 at para. 106.

The House of Lords recognized in White $v$. Chief Constable of South Yorkshire Police, [1999] 2 A.C. 455 at 511 , that it may not be practicable or even desirable to attempt to eliminate all inconsistencies in tort law.

" Supra note 5 at para. 43, citing the trial judge.

$72 \quad$ Hanke, supra note 1 at para. 28.

73 Supra note 5 at para. 97. 
deciding when proof of a hypothetical decision is possible is not a test conducive to certainty of result. Walker is a prime example.

\section{What Does Material Contribution Mean?}

Thus far, we have focused on what Hanke tells us about the first of the two questions that surround the material-contribution test: when is it available? We now tum to the second question: what does the test mean? What does it mean to say that antecedent condition $\mathrm{X}$ is a cause of consequence $Y$ under the material-contribution test? The Supreme Court of Canada has never offered any elucidation of this point. The main case, $M c G h e e,{ }^{74}$ on which it relied for holding that the material-contribution test was part of the common law, is famously vague. Canadian cases since $A t h e y$ have supplied different answers to this question. In England, the question of the definition of the material-contribution test was finally settled in Fairchild" and Barker ${ }^{76}$ as meaning nothing more than risk augmentation. A person whose actions materially increased the risk of the sort of injury the plaintiff had suffered had, on the material-contribution test, caused that injury in law. With such a radical definition of cause, it is no wonder the House of Lords held in Fairchild and Barker that it should be available only in rare circumstances.

Hanke does not attempt to offer a definition of "material contribution" or even to acknowledge the extent of the controversy surrounding it. However, the Supreme Court can hardly have been unaware of this debate or of the answers given in Fairchild and Barker. Moreover, its attempt to confine the material-contribution test to exceptional instances suggests that it accepts the radical, augmentation of risk meaning given to the materialcontribution test by the House of Lords. We suggest that additional proof of this can be found in the phrase that liability "may be imposed," which describes a consequence of the application of this new material-contribution test." The use of the word "imposed" implies recognition that factual causation cannot be established on any cause and effect basis but is being deemed to exist so that liability may be imposed if all other requirements are satisfied. However, confirmation of that, as with much else in the wake of Hanke, will have to await further litigation.

\section{CONCLusion}

We do not suggest that it is any easy matter to articulate a set of fair rules for when judges may resort to the material-contribution test. As we noted earlier, the House of Lords has devoted great effort to this. Its conclusions have not earned widespread acclaim. ${ }^{78}$

One form of doctrinal problem with the but-for test arises in cases where there are multiple causal candidates, each of which is independent of the others. ${ }^{79} \mathrm{~A}$ commonly-used example

4 Supra note 2.

is Supra note 10.

is Mid.

" Ilanke, supra note I at para. 25: quoted above in the text associated with supra note 35.

"Sec Jane Stapleton, "Lords a'Leaping Evidentiary Gaps" (2002) 10 Torts L.J. 276.

74 Scholarship calls this an overdelermined event. See H.L.A. Hart \& Tony Honoré, Causation in the Lau, 2d ed. (Oxford: Oxford University Press, 1985) at xxxix-xliii, 122-25, 235-49, 402-403, 455-56. 
involves a building destroyed by a fire. Assume that the fire was the combination of two fires, each starting independently of the other, each of which would have been sufficient to destroy the building by itself had it reached the building before the other rather than merging and reaching the building together as "one" fire. The but-for test fails in this situation precisely because each causal candidate (each fire) is a sufficient cause in conjunction with its own antecedent conditions, which do not include the other candidate cause. It is impossible to prove, on a but-for basis, that any of the causal candidates are the factual cause because the but-for test exonerates each of the candidates: there is always another but-for cause. The Hanke two-part test seems to provide us with an approach to answer to this dilemma. The dilemma satisfies the impossibility (of the use of but-for) branch. What is left is to determine whether the facts satisfy the other branch of the test.

There are other issues. Consider a key aspect of the test adopted by the House of Lords in Barker ${ }^{80}$ It was suggested that the material-contribution test should be available when the other candidate causal agents - those candidate caused agents other than the one set in motion by the defendant's negligence - operated the same way as did the agent attributable to the defendant's carelessness. The test was applicable in Barker because there the causal agent attributable to the defendant (asbestos dust) was the same as the other potential causal agents in play (asbestos dust from sources other than the defendant). However, the test would not be available when different candidate causal agents were involved. Thus, it would not be available on the facts of Wilsher v. Essex Area Health Authority, ${ }^{81}$ where the potential causal agent set in motion by the defendant was different from other causal agents which might have caused the plaintiff's injury.

As a criterion for deciding when the material-contribution test is or is not available, the single-agent/multiple-agent standard is far more certain than anything offered in Hanke. Yet is it any more satisfactory? It is hard to see why normative significance should attach to the single-agent factor. Doubt is doubt regardless of how many candidate causal agents there are for the plaintiff's harm, and the line chosen by the law lords seems arbitrary.

The House of Lords made a significant change to United Kingdom tort law in Barker in order to lessen the consequences of the application of the new material-contribution test. It held that any defendant which might be held liable on the new standard liable proportionally, only, not liable in solidum. ${ }^{82}$ The defendant is liable only for the amount of the plaintiff harm which corresponds with the extent to which the defendant augmented the already existing background risk ${ }^{83}$ of the plaintiff's suffering that same harm. It did so by deciding that riskaugmentation (coupled, of course, with manifestation of the relevant harm) was the actionable harm the plaintiff suffered. As an example, a defendant held liable for increasing the risk of the risk of the plaintiff's injury by 25 percent, assuming this satisfies the materialcontribution Fairchild/Barker test, would be liable only for 25 percent of the plaintiff's harm, never more.

Supra note 10.

[1988] A.C. 1074.

Several, not joint, in traditional terminology. The liability in Fairchild was joint; however, the issue of joint or several liability was not argued there.

Background risk meaning the cumulative risk of the harm occurring because of all other alternative sources of risk which are potential causes. 
Canadian Courts will have to grapple with this extent-of-the-amount-of-liability issue. Hanke provides no assistance. Nor does it provide assistance on a number of other issues. One problem is how to determine how much of an increase in risk is a sufficient increase to make it a significant unreasonable increase. It seems that the mere magnitude of the increase cannot be determinative. The negligence (standard of care) question only asks whether the increase in risk was unreasonable. This inquiry is qualitative in that it does not require the judge to quantify the amount of the increase. Another issue is whether contributory fault on the part of the injured person may now include conduct of the injured person which unreasonably augmented the risk of the harm which in fact occurred. In principle, it seems it should. Another problem is the application of the apportionment statutes. ${ }^{84}$ The statues will have to be amended or reinterpreted as the current understanding of their provisions founds the apportionment process on causative conduct which contributes to the injury, whether the apportionment is for contribution between tortfeasors or because the injured person is also at fault. ${ }^{85}$

The Supreme Court's judgment in Hanke does not address these matters. This was not surprising since it did not mention Fairchild, Barker or any scholarship on the material contribution test. Neither of the courts below considered these issues, and since the Supreme Court was not holding the defendants liable it was not necessary to deal with whether the Barker innovation, for example, should come to Canada. Similarly, the Court did not have to deal with the issue of contribution or contributory fault. However, future litigants defendants presumably - are certain to raise these issues.

Justice Sopinka wrote in Snell that "[c]ausation is an expression of the relationship that must be found to exist between the tortious act of the wrongdoer and the injury to the victim in order to justify compensation of the latter out of the pocket of the former." ${ }^{, k 6}$ The Hanke material-contribution test substitutes "imposed on" for "found to exist between." Supreme Court has been transforming the causation question from a scientific inquiry into a normative ruling in which the result depends on value judgment about how the costs of the injury should be allocated. ${ }^{88}$ Hanke is more evidence of that. In Bazley v. Curry, ${ }^{89}$ McLachlin J., as she then was, wrote of vicarious liability that the "fundamental question is whether the wrongful act is sufficiently related to conduct authorized by the employer to justify the imposition of vicarious liability." states the fundamental issue for all levels of the legal causation inquiry: is the wrongful act

See e.g. Contributory Negligence Act, R.S.A. 2000, c. C-27, Negligence Act, R.S.0. 1990, c. N-1. Heller v. Martens, 2002 ABCA 122, 303 A.R. 84; David Cheifetz, Apportionment of Fault in Tort (Aurora, Ont.: Canada Law Book. 1981). Stapleton, supra note 78, discusses the problems in apportionment where the basis of liability is risk-augmentation. Her discussion is in the context of apportionment for contribution between wrongdoers, but issues she identifies will also arise where there is contributory fault and therefore apportionment between wrongdoer and injured person.

Snell, supra note 2 at 326.

Hanke, supra note 1 at para. 25.

Black, "Dilution and 'Policyization,"' supra note 22. See also Wimnipeg Child and Family Services (Northiest Area) v. G. (D.F.). [1997] 3 S.C.R. 925 at para. 12, quoting Tremblay v. Daigle. [1989] 2 S.C.R. 530 at 553 that the creation of rights and duties is a normative task that "falls outside the concerns of scientific classification."

[1999] 2 S.C.R. 534.

lbid. at para. 41 [cmphasis in original]. 
sufficiently related to the consequence to justify the imposition of liability on a particular defendant?

The Hanke explanation of the two general principles that will now govern Canadian law about when the material-contribution test is applicable does not clarify any uncertainty. Instead, it conflates and confuses the separate questions of the empirical issue of causal contribution and the normative issue of legal responsibility. The numerous uncertainties that arise from Hanke suggest that the material-contribution test for factual causation and its consequences will be the subject of litigation for years to comc. ${ }^{91}$ Hanke stands as a missed opportunity to clarify significant aspects of causation doctrine. ${ }^{92}$ involving necrotizing fasciitis, but has been refused: see Aristorenas v: Comcare Healih Services (2006), 83 O.R. (3d) 282, leave to appeal to S.C.C. refused. 31760 (29 March 2007).

There is another curious, but now moot, anomaly in the Supreme Coun causation jurispredence. The last two references to factual causation and the but-for and malerial-contribution tests before Hanke, are K.I.B. v. British Columbia, 2003 SCC 51, [2003] 2 S.C.R. 403 at para. 13 [K.L.B.] and H. L. v. Canada (Attorney General), 2005 SCC 25, [2005] I S.C.R. 401 at para. 123 (II.I.]. Both are intentional sexual assault cases that involve vicarious liability. The plaintiffs in these eases argued direct negligence against British Columbia and Canada, respectively. In K.L.B. the Court stated clearly that the only lest for factual causalion in all cases of negligence is the but-for test as explained in Snell (at para. 13). There is no mention of the material-contribution test anywhere in K.L.B. Athe' is mentioned on a damages issue (at para. 60). I.L. was relcased about cightcen montlss after $K . L . B$. In this case, the patiring of the but-for and material-contribution tests has returned in its traditional Athey formulation. The Court also referred to the standard portions of $A$ they' (at para. 28); K.L.B. was not mentioned. Both cases had ninejudge panels. 